\title{
Antimicrobials administration time in patients with suspected sepsis: faster is better for severe patients
}

\author{
Romain Jouffroy ${ }^{*}$ (D) and Benoît Vivien
}

\begin{abstract}
In a recent report, Ascuntar et al. describes the impossibility to demonstrate a significant association between early antibiotic therapy administration and mortality in sepsis patients. Nevertheless, we believe that some methodological issues deserve their conclusions. First, the objective of the authors of an early antibiotic therapy may be ambitious considering practical daily emergency department limitation. Second, most of patients included in the study appear to suffer from sepsis and not from septic shock, which limits the impact of an early and aggressive management. At last, more than a single intervention such as antibiotic therapy, sepsis treatment is now considered as based on a "bundle of care."
\end{abstract}

Keywords: Antibiotic therapy, Sepsis, Early, Mortality, Confounder, Methodological issue

To the Editor:

We read with great interest the recent paper published in the Journal by Ascuntar et al [1]. reporting the impossibility to demonstrate a significant association between early antibiotic therapy administration and mortality in sepsis patients. Undoubtedly, the authors must be complimented for this interesting study in the controversial field of early antibiotic therapy administration in case of suspected or confirmed sepsis. Nevertheless, we believe that some methodological issues deserve their conclusions.

Firstly, the database used by the authors for this analysis comes from a previous prospective study [2], in which they had concluded that an early antibiotic therapy use, i.e. within $3 \mathrm{~h}$ after emergency department (ED) admission, had the greatest impact on survival on septic shock patients. However, this recommendation may be ambitious considering practical daily ED limitations: on

\footnotetext{
* Correspondence: romain.jouffroy@aphp.fr

SAMU de Paris, Service d'Anesthésie Réanimation, Hôpital Universitaire Necker - Enfants Malades, Assistance Publique - Hôpitaux de Paris, AP-HP.Centre and Université de Paris, Paris, France
}

the one hand, since the 2016 SEPSIS-3 international consensus, septic shock definition requires lactatemia assessment and/or norepinephrine administration after adequate fluid expansion, which is time-consuming and frequently requires more than $3 \mathrm{~h}$; furthermore, in situation of ED overcrowding, following these guidelines is much more difficult, and initial severity assessment of sepsis patients could only be based on clinical symptoms.

Secondly, in the study of Ascuntar et al., the overall hospitality mortality rate was low $(11.5 \%)$, suggesting that most of patients suffered from sepsis and not from septic shock, for which mortality rate usually reaches 40 to $50 \%$ [3]. Although this point was stressed by the authors in their article [1], we think that this is the major limitation of this work, precluding any application of the results to septic shock patients.

Thirdly, considering either the 1-h or the 3-h threshold, the patients who presented with a lower systolic blood pressure were those who received early antibiotics, that is clinically fully comprehensible. Conversely, we could hypothesize that a late antibiotic administration in 
the less severe patients could have worsen their prognosis to the level of the most severe ones but who received an early treatment, this finally being an explanation for the absence of difference in mortality between groups.

Last but not least, more than a single intervention, sepsis treatment is based on a bundle of care, as mentioned by Ascuntar et al. in the background of their article [1]. Among many clinical and paraclinical elements, hemodynamic optimization is one of the two most important $[2,4]$. Nevertheless, the authors did not use a logistic regression model to take into account the blood pressure reached, which is a major confounder [1]. Indeed, for the antibiotics to reach infected tissues, the restoration of a sufficient tissue perfusion pressure is a fundamental prerequisite [5].

Finally, we fully agree with Ascuntar et al. that early identification of sepsis, especially those at risk of unfavorable evolution, is difficult and a daily challenge. Nevertheless, we believe that while assessment of sepsis severity is a crucial step prior to treatment instauration in order to reduce sepsis mortality rate, on the opposite, indiscriminate and inappropriate use of antibiotics may be a major factor for antimicrobial resistance.

\section{Abbreviations}

ED: Emergency department

\section{Acknowledgements}

None

\section{Authors' contributions}

BV and RJ wrote the manuscript. The authors read and approved the final manuscript.

\section{Funding}

None

Availability of data and materials

Not applicable

Ethics approval and consent to participate

Not applicable

Consent for publication

Not applicable

\section{Competing interests}

None

Received: 23 May 2020 Accepted: 15 July 2020

Published online: 22 July 2020

\section{References}

1. Ascuntar J, Mendoza D, Jaimes F. Antimicrobials administration time in patients with suspected sepsis: is faster better? An analysis by propensity score. J Intensive Care. 2020 Apr 22;8:28.

2. Londoño J, Niño C, Archila A, et al. Antibiotics has more impact on mortality than other early goal-directed therapy components in patients with sepsis: an instrumental variable analysis. J Crit Care. 2018:48:191-7.

3. Luhr R, Cao Y, Soderquist B, Cajander S. Trends in sepsis mortality over time in randomised sepsis trials: a systematic literature review and meta-analysis of mortality in the control arm, 2002-2016. Crit Care. 2019;23(1):241.
4. Rhodes A, Evans LE, Alhazzani W, Levy MM, Antonelli M, Ferrer R, et al. Surviving Sepsis Campaign: international guidelines for management of sepsis and septic shock: 2016. Intensive Care Med. 2017;43:304-77.

5. Jouffroy $R$, Vivien B. Implementation of earlier antibiotic administration in patients with severe sepsis and septic shock in Japan: antibiotic action needs time and tissue perfusion to reach target. Crit Care. 2020 Jan 14;24(1): 17.

\section{Publisher's Note}

Springer Nature remains neutral with regard to jurisdictional claims in published maps and institutional affiliations.
Ready to submit your research? Choose BMC and benefit from:

- fast, convenient online submission

- thorough peer review by experienced researchers in your field

- rapid publication on acceptance

- support for research data, including large and complex data types

- gold Open Access which fosters wider collaboration and increased citations

- maximum visibility for your research: over $100 \mathrm{M}$ website views per year

At $\mathrm{BMC}$, research is always in progress.

Learn more biomedcentral.com/submissions 